\title{
OPTIMALISASI PERAN GURU DALAM MENDIDIK KARAKTER SISWA MELALUI MEDIA TEMBANG MACAPAT PANGKUR
}

\author{
Sarafuddin $^{1, \mathrm{a}}$ dan Winarto ${ }^{1, \mathrm{~b}}$ \\ ${ }^{1}$ Program Studi Pendidikan Guru Sekolah Dasar \\ Universitas Slamet Riyadi Surakarta, 57126, Indonesia \\ asarafuddinmj11@gmail.com \\ ${ }^{1}$ Program Studi Pendidikan Guru Sekolah Dasar \\ Universitas Slamet Riyadi Surakarta, 57126, Indonesia \\ bwinbarog19@gmail.com
}

\begin{abstract}
Abstrak
Kegiatan Pengabdian masyarakat ini bertujuan untuk mengoptimalkan peran guru dalam mendidik karakter peserta didik melalui media tembang macapat pangkur di SDN 02 Gaum Tasikmadu Karanganyar. Peran guru di sekolah sangat berpengaruh pada kemajuan dan perkembangan karakter peserta didik untuk mengenali dan mencintai seni dan budaya daerahnya. Selama ini kadang-kadang guru di sekolah hanya sekedar melaksanakan kewajiban mengajar dengan tuntutan ketercapai ketuntasan materi pembelajaran. Artinya bahwa guru di sekolah kurang maksimal dalam memanfaatkan media pembelajaran terutama media berbasis seni untuk mendidik karakter peserta didik. Kondisi ini diperoleh berdasarkan hasil survey yang awal yang dilakukan di SDN 02 Gaum Tasikmadu Karanganyar. Pengabdian ini dilakukan di SDN 02 Gaum Tasikmadu Karanganyar. Metode pelaksanaan pengabdian meliputi: (1) metode pendekatan yang dilakukan mulai tahap survei, dan perijinan, dan (2) metode pelaksanaan program, meliputi tahap pendahuluan, tahap sosialisasi dan audiensi, tahap pelaksanaan dan kolaborasi, dan tahap evaluasi. Target luaran yang dihasilkan adalah 9 guru dari 12 guru yang mengikuti pelatihan ini mampu menyusun materi pembelajaran seni berbasis kearifan lokal. Luaran yang dihasilkan berupa materi pembelajaran seni tembang macapat pangkur serta publikasi artikel pengabdian dalam jurnal ilmiah. Diharapkan dengan adanya kegiatan ini akan dapat memberikan penguatan pemahaman pada guru-guru tentang betapa pentingnya pendampingan dalam menanamkan karakter peserta didik. Kondisi tersebut tidak bisa dipungkiri bahwa apabila peserta didik didekatkan dan diajarkan tentang kearifan lokal seperti tembang macapat pangkur, maka pada diri mereka akan tumbuh karakter baik yaitu kecintaan terhadap seni dan budaya daerahnya.
\end{abstract}

Kata Kunci: Peran guru, pendidikan karakter, media tembang macapat pangkur.

\section{Pendahuluan}

Tembang macapat adalah sebuah bentuk tembang (menyanyi) jawa, yang menggunakan laras musik jawa pelog atau slendro (pentatonik atau diatonis) yang berpegang pada guru lagu dan guru wilangan. guru lagu adalah tibaning lagu swara ing pungkasaning gatra atau gendhing. guru wilangan adalah jumlahing lagu atau swara ing pungkasaning gatra. Artinya bahwa dalam tembang macapat terdapat sebuah teknik dan aturan yang harus ditaati. Berdasarkan penjabaran di atas, maka sangat perlu dan penting di dalam kurikulum tingkat pendidikan 
dasar untuk masukkan tembang macapat sebagai mata pelajaran wajib guna memperkuat sendi kearifan lokal yang basis seni dan budaya. Melalui upaya tersebut dapat mempermudah guru memberikan pemahaman kepada peserta didiknya untuk mengenal dan mampu mengimplementasikan seni budaya daerahnya.

Pendidikan dasar merupakan sebuah kunci utama untuk membentuk kepribadian dan karakteristik manusia. Berhasil atau tidak dan berkualitas atau tidak, tergantung pada metode penyampaian pembelajarannya. Guru sekolah dasar mempunyai peran penting terhadap kegiatan belajar mengajar dalam rangka mewujudkan embrio manusia yang berkualitas baik yang didasari akhlak mulia, berbudi pekerti luhur, dan berjiwa Pancasila. Namun sangat disayangkan bahwa kemampuan paralel seorang guru relatif terbatas bahkan kebanyakan lebih menitik beratkan pada satu bidang keahlian dan jauh dari aspek seni. Perlu dipahami bahwa tembang macapat, tari, dan teater adalah bidang seni yang sangat langka tetapi mudah untuk dipelajari dan dikuasai baik oleh guru maupun peserta didik.

Melihat kenyataan yang berkembang di masyarakat bahwa tenaga pendidik atau guru dalam skala mayoritas kurang memahami tembang macapat dan nilai-nilai yang terkandung didalamnya. Salah satu solusi untuk mengatasi fenomena tersebut, maka sangat perlu diselenggarakan pendidikan dan pelatihan. Pendidikan dan pelatihan ini dispesifikasikan pada tembang macapat yang dilengkapi dengan penjabaran filosofi dan nilai-nilai positif yang terkandung di dalamnya, bersifat mengajarkan kebaikan dan mengajak manusia untuk selalu berhati-hati dalam setiap prilaku dan perbuatannya. Tembang Macapat Pangkur merupakan salah satu pilihan yang dipandang tepat untuk disampaikan kepada guru-guru sekolah dasar bila dibandingkan dengan 10 tembang macapat lainnya seperti; (1) Mijil, (2) Kinanthi, (3) Sinom, (4) Asmarandana, (5) Dhandhang Gula, (6) Maskumambang, (7) Durma, (8) Gambuh, (9) Megatruh, dan (10) Pocung. Alasan yang paling mendasar memilih Tembang Macapat Pangkur sebagai materi pendidikan dan pelatihan karena berifat mudah dipelajari dan karakternya sangat mendidik.

\section{Metode Pelaksanaan}

Metode pendekatan yang dilakukan mulai (1) tahap survei, perijinan, dan pemberian motivasi bagi guru yang akan mengikuti pelatihan (2) metode pelaksanaan program, meliputi tahap pendahuluan, tahap sosialisasi dan audiensi, tahap pelaksanaan, serta tahap evaluasi akhir.

Tahap pendahuluan dilaksanakan dengan mempersiapkan surat ijin dengan pihak terkait, mempersiapkan tempat pelatihan, mempersiapkan materi, alat dan bahan. Tahap sosialisasi dan audiensi dilakukan dengan cara memberikan pelatihan penyusunan materi pembelajaran seni berbasis kearifan lokal berupa tembang macapat pangkur dengan cara mengumpulkan guru-guru dan peserta didik SD 
negeri 02 Gaum Tasikmadu Karanganyar, pengabdian masyarakat yang telah kemudian memberikan penjelasan kepada dilaksanakan, sehingga dapat diketahui bahwa tentang pentingnya menanamkan pendidikan para guru khususnya guru yang mengajar materi karakter kepada peserta didik melalui seni pembelajaran seni pemahamannya semakin budaya lokal.

Tahap pelaksanaan kegiatan pelatihan dilakukan dengan memulai pelatihan penyusunan dan sosialisasi program dengan metode ceramah partisipatif, interaktif, dan dialogis. Melalui metode ini, peserta pelatihan dengan mudah dapat memahami dan mencerna yang kemudian diterapkan dalam menyusun materi pembelajaran mereka masing-masing. Di samping itu proses pelaksanaan pengabdian juga dilakukan dengan metode ceramah, tanya jawab, diskusi, dan praktek secara langsung oleh peserta.

Tahap evaluasi kegiatan dilakukan dengan cara mengevaluasi kegiatan pelatihan penyusunan materi pembelajaran seni berbasis kearifan lokal dalam bentuk tembang macapat pangkur, kemudian dianalisis kelebihan dan kekurangannya selama pelaksanaan kegiatan pengabdian masyarakat berlangsung.

\section{Hasil dan Pembahasan}

Hasil yang dicapai dari kegiatan pengabdian kepada masyarakat ini adalah meningkatnya kemampuan dan keterampilan guru SD negeri 02 Gaum Tasikmadu dalam penyusunan materi pembelajaran seni yang berbasis kearifan lokal seperti tembang macapat pangkur. Kondisi ini terlihat berdasarkan hasil evaluasi dan simulasi pada pelatihan kegiatan

meningkat. Indikatornya adalah semula peserta belum memahami dan terampil dalam menyusun dan mengajarkan materi pembelajaran seni tembang macapat pangkur, maka setelah mengikuti kegiatan pelatihan tersebut, kemampuan dan ketrampilan guru meningkat. Guru dapat mengerti dan memahami betapa pentingnya makna edukatif dari pembelajaran materi seni bersumber dari kearifan lokal karena dapat menumbuhkan karakter positif pada peserta didik berupa kecintaan mereka terhadap seni budaya daerahnya. Kegiatan pelatihan ini direncanakan diikuti oleh 20 orang peserta, terdiri dari 12 orang guru dan 8 orang peserta didik. Artinya target yang direncanakan bahwa dari jumlah peserta yang mengikuti pelatihan diharapkan $75 \%$ peserta yang hadir yaitu 9 orang guru dan 5 orang peserta didik telah berubah pandangan mereka tentang pentingnya pembelajaran kearifan lokal berupa seni tembang macapat pangkur. Keadaan ini dirasa cukup berhasil mengingat SD negeri 02 Gaum merupakan sekolah dasar yang cukup maju dengan pengelola atau manajemen sekolah terdiri dari 1 orang kepala sekolah dan 15 orang guru kelas serta guru bidang studi.

Mengingat bahwa salah satu tugas guru adalah mendidik, karena mendidik merupakan salah satu pekerjaan yang tidak gampang atau 
tidak mudah sebab dalam mendidik seorang guru harus mampu menanamkan akhlak serta budi pekerti yang baik, sehingga bisa membentuk pribadi yang, jujur, dan bertanggungjawab. Melalui tembang pangkur pupuh pertama tersebut di atas diharapkan dapat mempermudah guru dalam pembelajaran dan mendidik akhlak serta budi pekerti yang baik. Hal ini disebabkan bahwa di dalam tembang pangkur pada setiap gatranya telah mengandung nilai-nilai ajaran kehidupan yang sangat luhur dan baik. Dengan mempelajari tembang macapat pangkur yang mempuyai watak serta karakteristik seperti tersebut di atas, di harapkan mampu membangun spirit yang bisa membangkitkan jiwa keberanian dan kesetiakawanan dalam rangka mewujudkan kualitas sumber daya manusia yang profesional dan berkomitmen tinggi untuk selalu menjaga kebersamaan dan kegotong royongan dalam setiap interaksi manusia sebagai mahluk sosial.

Sangat diharapkan setelah kegiatan ini, untuk tahun pelajaran berikutnya dapat dicantumkan dalam program kerja sekolah yang berisi kegiatan pelatihan terkait dengan penyusunan materi pembelajaran seni berbasis kearifan lokal. Selain itu juga dapat dilakukan pelatihan penyusunan nada dan notasi untuk berbagai macam tembang lainnya sehingga dapat mempermudah guru dalam membelajarkannya pada peserta didik yang saat ini menjadi salah satu kelemahan di SD negeri 02 Gaum. Rencana ini muncul berdasarkan masukan dari beberapa guru khususnya yang mengajar mata pelajaran seni dengan indikasi mereka mengalami kusilitan dalam menyampaikan pembelajaran terutama pada aspek nada dan notasi. Bila ke depan rencana ini terrealisasi, maka pelaksana kegiatan membuat perencanaan yang lebih sistematis dengan mengarah pada praktek dan simulasi sehingga peserta memiliki pengetahuan yang lebih luas dan jelas.

Pelaksanaan kegiatan pengabdian masyarakat ini merupakan suatu rangkaian tahapan-tahapan kegiatan yang akan direncanakan sebagai kegiatan yang berkelanjutan. Tahap berikutnya yang direncanakan adalah mengadakan kegiatan berupa pelatihan yang berisi kegiatan workshop terkait dengan penyusunan materi pembelajaran seni berbasis kearifan lokal. Dalam hal ini lebih difokuskan pada pelatihan penyusunan nada dan notasi untuk berbagai macam tembang lainnya sehingga dapat mempermudah guru dalam membelajarkannya pada peserta didik yang saat ini menjadi salah satu kelemahan dan menjadi masalah yang urgent bagi guru di SD negeri 02 Gaum Tasikmadu Karanganyar.

Bila dilihat dari potensi yang dimilik, SD negeri 02 Gaum merupakan lembaga formal milik pemerintah yang senantiasa sangat mudah untuk memasukkan unsur-unsur kearifan lokal dalam pembelajaran seni dan sangat dimungkinkan untuk diprogramkan dalam kurikulum muatan lokal. Melalui kurikulum muatan lokal tersebut, diharapkan dapat menjadi pedoman bagi guru seni dalam menyusun 
perangkat pembelajaran berbasis kearifan lokal seperti seni tembang macapat. Apabila rencana ini ke depan dapat diwujudkan, maka tentunya akan terlihat mutu dan kualitas guru dan peserta didik semakin bertambah karena potensi yang dimilikinya dapat digali dan sekaligus dapat dipraktekkan dalam kegiatan pembelajaran. Di sisi lain, karakter peserta didik juga akan menjadi baik sebab pada diri mereka tumbuh kecintaan terhadap nilai-nilai tradisi dan budaya yang ada di daerahnya.

Berdasarkan pernyataan tersebut, maka tembang macapat sangat memungkinkan untuk diajarkan di tingkat pendidikan dasar karena dapat dijadikan sebagai sarana atau media pembelajaran pendidikan karakter. Sebuah kenyataan bahwa pada hakekat manusia hidup dan dilahirkan di dunia ini tidak hanya menjalani proses kehidupan tanpa tindakan apapun, akan tetapi banyak manusia yang tidak menyadari tentang makna hidup sejati sehingga dia lebih menikmati dan terlena pada keindahan dunia yang sebenarnya itu adalah kiasan hidup yang semu dan menipu manusia itu sendiri. Oleh karena itu, pendidikan karakter harus betul-betul menjadi prioritas utama dalam setiap bentuk pembelajaran lebih-lebih lebih pembelajaran seni berbasis kearifan lokal.

Sehubungan dengan keberlanjutan pelatihan penyusunan materi pembelajaran seni berbasis kearifan lokal yang difokuskan pada pelatihan penyusunan nada dan notasi untuk berbagai macam tembang, maka rencana tahapan berikutnya adalah melakukan workshop dan langsung praktek. Kegiatan tersebut diformulasi seperti itu, dengan tujuan agar guru dapat mengembangkan kompetensinya tidak hanya pada penyusunan perangkat pembelajaran saja tetapi lebih mengarah pada penyusunan bahan ajar yang berisi nada dan notasi tembang macapat. Melalui workshop dan pelatihan diharapkan guru akan lebih memahami dan menguasai terkait pentingnya membelajarkan seni berbasis kearifan lokal yang dapat menumbuhkan karakter positif pada peserta didiknya.

\section{Kesimpulan dan Saran}

\section{Kesimpulan}

Berdasarkan uraian uraian di atas, bahwa kegiatan pengabdian masyarakat bagi guru dan peserta didik SD negeri 02 Gaum Tasikmadu dapat disimpulkan sebagai berikut:

1. Pelatihan dan sosialisasi penyusunan materi pembelajaran seni berbasis kearifan lokal yang dilaksanakan dapat menigkatkan kemampuan dan pemahaman guru dalam menyusun materi pembelajaran dalam bentuk seni tembang macapat pangkur, sedangkan bagi peserta didik dapat tertanam karakter yang baik dan positif dalam bentuk kecintaan mereka terhadap tradisi dan seni budaya daerahnya.

2. Menemukan masalah mendasar terhadap belum optimalnya pemanfaatan kearifan lokal dalam bentuk seni tembang macapat pangkur sebagai kemasan materi pembelajaran khususnya mata pelajaran seni, 
dimana guru masih merasa kesulitan dalam menyusun nada dan notasinya.

\section{Saran}

Berdasarkan kesimpulan di atas, dapat dikemukakan saran-saran sebagai berikut:

1. Pelaksanaan kegiatan pelatihan dan sosialisasi penyusunan materi pembelajaran seni berbasis kearifan lokal ini diharapkan dapat dilanjutkan kepada pelatihan, workshop dan praktek penyusunan nada dan notasi tembang macapat bagi guru SD negeri 02 Gaum.

2. Untuk meningkatkan pengetahuan dan keterampilan guru dalam menyusun materi pembelajaran seni berbasis kearifan lokal berbentuk seni tembang macapat, maka diharapkan adanya pelatihan, workshop dan praktek penyusunan nada dan notasi secara intensif agar guru lebih memahami tentang seni tembang macapat tersebut.

\section{Daftar Pustaka}

Barnawi \& M. Arifin, 2012. Strategi \& Kebijakan Pembelajaran Pendidikan Karakter. Yogyakarta: Ar-ruzz Media.

Furqon Hidayatullah, 2010. Pendidikan Karakter: Membangun Peradaban Bangsa. Surakarta: PT. Yuma Perkasa. http://www.longlifeducation.com/2011/12/temba ng-macapat pangkur.htm?m=1

http://megayumalia.blogspot.co.id/2015/08/bah asa-jawa-tembang-pangkurpangertene. $h$ tmI $? \mathrm{~m}=1$

Jamal Ma'mur Asnani, 2012. Buku Panduan Internalisasi: Pendidikan Karakter di Sekolah. Yogyakarta: Diva Press.

LPPM UNISRI.2013. Panduan Penelitian dan Pengabdian Pada Massyarakat. Surakarta. Universitas Slamet Riyadi.

Masnur Muslich, 2011. Pendidikan Karakter: Menjawab Tantangan Krisis Multidimensional. Jakarta: PT. Bumi Aksara.

M. Noor Rohinah, 2012. Mengembangkan Karakter Anak Secara Efektif di Sekolah dan di Rumah. Yogyakarta: PT. Pustaka Insan Madani.

Ida Zusnani, 2012. Manajemen Pendidikan Berbasis Karakter Bangsa. Jakarta: Tugu Publisher.

Setiyoko Fajar. 2017, Kumpulan Tembang Macapat Lengkap dengan Penjelasan dan Contohnya. 